\title{
Wpływ koncepcji odpoczynku na zrównoważoną turystykę
}

\author{
Ryszard F. Sadowski \\ Instytut Ekologii i Bioetyki, Wydział Filozofii Chrześcijańskiej \\ Uniwersytet Kardynała Stefana Wyszyńskiego w Warszawie, ul. Wóycickiego 1/3, 01-938 Warszawa \\ r.sadowski@uksw.edu.pl•ORCID: 0000-0002-5452-2168
}

\section{Streszczenie}

Artykuł prezentuje 1) ewolucję koncepcji odpoczynku; 2) wyzwania, jakie współczesna cywilizacja stawia wobec odpoczynku oraz 3) koncepcję odpoczynku, która wspiera zrównoważoną turystykę. Zdaniem autora tylko odpoczynek, który uwzględnia całą potencjalność człowieka wraz z jego potrzebami biologicznymi, emocjonalnymi i kulturowo-duchowymi gwarantuje skuteczne uprawianie turystyki zrównoważonej. Ważną rolę w dochodzeniu do takiej koncepcji odpoczynku odgrywa nauczanie i wychowanie.

\section{Stowa kluczowe}

odpoczynek, czas wolny, turystyka zrównoważona, zrównoważony rozwój

\section{Wprowadzenie}

Wypoczynek jest istotnym elementem wszystkich ważniejszych definicji turystyki. Przy jej opisie często używa się bowiem takich określeń, jak przerwa w pracy zarobkowej, czas wolny i odpoczynek ${ }^{1}$. Potwierdza to m.in. uznawana za klasyczną, definicja turystyki Waltera Hunzikera, który podaje, że turystyka jest to zespół stosunków i zjawisk, które wynikają z podróży i pobytu osób przyjezdnych, jeśli nie występuje w związku z tym osiedlenie i podjęcie pracy zarobkowej. Jeszcze wyraźniej element czasu wolnego podkreśla definicja turystyki autorstwa Marca Boyera - turystyka to aktywność czasu wolnego, zakładająca zmianę miejsca

1 W opracowaniu tym terminy „czas wolny” i „odpoczynek” są traktowane zamiennie i są bliskie znaczeniowo angielskiemu określeniu "leisure”. pobytu, a ruch i poruszanie się jest tym, co czyni turystę (Panasiuk 2006: 22-23). W podobnym duchu wypowiada się Valene L. Smith, która twierdzi, że turysta jest osobą czasowo wolną od obowiązków, która dobrowolnie odwiedza miejsce $\mathrm{z}$ dala od domu w celu doświadczenia zmian (Smith 1989: 1). Zatem próba określenia turystyki zrównoważonej musi uwzględniać koncepcję odpoczynku, która będzie wspierała zasadę zrównoważonego rozwoju.

Zagadnienie to wydaje się tym bardziej istotne, że turystyka stała się jedną $\mathrm{z}$ ważniejszych gałęzi światowej gospodarki. Szacuje się, że na rzecz turystyki pracuje obecnie ok. $9 \%$ wszystkich zatrudnionych na świecie osób, przemysł turystyczny wypracowuje $10 \%$ światowego PKB oraz przyczynia się do $7 \%$ światowego eksportu (UNWTO 2016). W sposób nieunikniony 
turystyka wpływa więc na stan środowiska przyrodniczego, rozwój ekonomiczny i społeczny. Z tego powodu ONZ podkreśla wagę turystyki dla starań na rzecz zrównoważonego rozwoju świata. Jedną z inicjatywy ONZ zmierzających do uzgodnienia turystyki z ideą zrównoważonego rozwoju jest rezolucja Zgromadzenia Ogólnego z 22 grudnia 2015 roku, w której ogłoszono rok 2017 Międzynarodowym Rokiem Zrównoważonej Turystyki na Rzecz Rozwoju (UN 2015). Zasadniczym celem tej inicjatywy jest taki rozwój turystyki, który przyczyni się do: 1) inkluzywnego i zrównoważonego wzrostu gospodarczego; 2) integracji społecznej, wzrostu zatrudnienia oraz redukcji ubóstwa; 3) efektywnego wykorzystywania zasobów naturalnych, ochrony środowiska i zapobiegania zmianom klimatycznym; 4) ochrony różnorodności dziedzictwa kulturowego; oraz 5) wzajemnego zrozumienia, pokoju i bezpieczeństwa (UNWTO 2016).

Wydaje się zatem, że refleksja nad odpoczynkiem może pomóc w zbudowaniu takiego modelu turystyki, który pozwoli skuteczniej zrealizować cele przyświecające ONZ przy ogłaszaniu Międzynarodowego Roku Zrównoważonej Turystyki na Rzecz Rozwoju. Celem tego opracowania jest więc wskazanie koncepcji odpoczynku, będącego inspiracją do integralnego i wszechstronnego rozwoju człowieka, który przyczyni się do uprawiania turystyki zrównoważonej.

\section{Historyczne ujęcie wypoczynku}

Istnieje przekonanie, że powszechnie dostępny odpoczynek/czas wolny (ang. leisure) jest osiągnięciem XX wieku, podczas gdy wcześniej człowiek zawsze zmuszony był do nieustannej, mozolnej pracy w celu zdobywania środków niezbędnych do życia. Współczesne badania zdają się kwestionować to przekonanie. Odkrycia historyków środowiska wskazują bowiem, że już przed rewolucją neolityczną istniały społeczności zbieracko-łowieckie, które potrzebowały zaledwie 4-6 godzin pracy dziennie, by zaspokoić wszystkie swoje potrzeby materialne (Sutton i Anderson 2004: 134; Sahlins and
Graeber 2017: 1-40). Badania wskazują jednak, że przedstawiciele tych społeczności najczęściej czas wolny spędzali bezczynnie (Chick 1984: 624-625).

Sposób odpoczywania zmieniał się wraz z rozwojem cywilizacji. Wykształcenie się warstw społecznych spowodowało, że odpoczynek stał się dobrem dostępnym jedynie dla uprzywilejowanych części społeczeństw. Umożliwiło to intensywny rozwój kultury, a co za tym idzie, także refleksję nad samym odpoczynkiem. Dobrze ilustruje to rozwój cywilizacji greckiej, w której odpoczynek stał się przedmiotem refleksji filozofów. Grecy na określenie odpoczynku (ang. le-

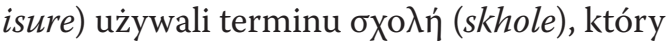
znaczył pierwotnie tyle, co wolny czas, bezczynność, spokój, odpoczynek, ulga, rozrywka, rozmowa, dysputa (Jurewicz 2001: 375-376). Z czasem zaczęli jednak rozumieć

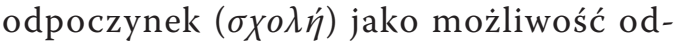
dawania się sprawom związanym z wartościami. Czas wolny był do tego konieczny, umożliwiał bowiem rozwój umiejętności i zdobycie wiedzy niezbędnej do tak rozumianego odpoczynku, ale nie był z odpoczynkiem tożsamy. Stąd starożytni Grecy rozróżniali $\sigma$ xoג'́ (skhole) odpoczynek od $\pi \alpha \iota \delta \iota \alpha ́$ (paidia) zabawy, igraszki, rozrywki

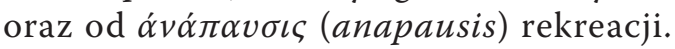
Rozrywka (paidia) i rekreacja (anapausis) umożliwiały wytchnienie nie tylko od pracy, ale także od mozolnego odpoczynku (skhole), który był związany z wysiłkiem intelektualnym. Termin „odpoczynek” (skhole) był bowiem zarezerwowany dla najbardziej wartościowych - zdaniem Greków - aktywności, które były podejmowane ze względu na nie same, nie zaś ze względu na wytchnienie od mozołu życia czy użyteczność. Takie ujęcie zagadnienia podkreślało zasadniczą różnicę między odpoczynkiem a bezczynnością. Grecy wskazywali także na różnicę między tak rozumianym odpoczynkiem (skhole) a pracą (askholia), którą określali jako brak odpoczynku (skhole). Przeciwstawienie odpoczynku i pracy potwierdza sam kształt obu terminów $\sigma \chi 0 \lambda \eta \dot{~(s k h o l e) ~}$ i $\alpha \sigma x o \lambda i \alpha$ (askholia) (Sager 2013: 5-6). 
Początki filozoficznej refleksji nad odpoczynkiem mają więc swoje źródła w kulturze greckiej, a szczególnie w pismach Platona i Arystotelesa. Platon przyczynił się do swoistego rozumienia odpoczynku (skhole) poprzez stwierdzenie, że kontemplatywne życie filozoficzne jest bardziej wartościowe, niż życie czynne, zaangażowanie w sprawy codzienne. Niezbędnym warunkiem filozofowania był bowiem odpoczynek (skhole). W Prawach Platon stwierdza, że bogowie litując się nad człowiekiem skazanym na trud, obdarowali go odpoczynkiem ustanawiając święta, którym towarzyszyły Muzy - greckie boginie sztuki i nauki oraz przewodzący im Apollo (Platon 1997: 54, 2.653C-d).

Tematykę odpoczynku podjął także Arystoteles. W Etyce nikomachejskiej wskazał, że najwyższym celem człowieka, jest rozumna aktywność dążąca do celu ze względu na niego samego, nie zaś na korzyści (Arystoteles 1996: I,7). Dlatego najbardziej godnym człowieka jest życie kontemplatywne (Arystoteles 1996: X,7). Arystoteles twierdził ponadto, że do pełni człowieczeństwa niezbędny jest odpoczynek, który pozwala realizować cele dla nich samych. Pomocą w tym względzie są artes liberales, które w odróżnieniu od artes serviles prowadzą do zaspokojenia najwyższych aspiracji człowieka, które nie wiążą się wprost z użytecznością (Sager 2013: 7). Zdaniem Arystotelesa odpoczynek jest tak wielkim wyzwaniem dla człowieka, że wymaga gruntownego przygotowania, tzn. właściwego wychowania do odpoczynku oraz nabycia niezbędnej wiedzy (Arystoteles 2003: VIII,2.5).

Rozumienie odpoczynku w cesarstwie rzymskim w dużej mierze pokrywało się $\mathrm{z}$ myślą grecką. Rzymianie z reguły ujmowali odpoczynek jako bezinteresowne dążenie do celu ze względu na sam cel (Sager 2013: 7). Na określenie odpoczynku używali terminu otium, który oznacza także spokój, czas wolny, bezczynność, lenistwo, próżnowanie, ale też czas przeznaczony na pracę umysłową. Pracę rozumieli zaś jako zaprzeczenie odpoczynku negotium. Widać to w analogicznej do greki budowie obu terminów: łac. otium i neg-otium oraz gr. skhole i a-skholia. Łaciński termin negotium oznaczał ponadto zatrudnienie, zajęcie, obowiązki, przedsięwzięcie, interesy, sprawy (Sondel 1997: 701-702; 654).

Refleksja nad odpoczynkiem była podejmowana w twórczości najwybitniejszych myślicieli rzymskich. Cyceron, skazany przez Cezara na wygnanie, spędzał czas na pisaniu rozpraw filozoficznych Tusculanae disputationes. Sam określił ten okres swego życia jako odpoczynek z godnością (łac. otium cum dignitate) (Cicero 2017: XLV,[98]). Odpoczynek rozumiał zaś jako czas wolny od zaangażowania w działalność polityczną, a nawet jako stan bezpieczeństwa i pokoju - rodzaj „zdrowia publicznego" (Cyceron 1960: III,I, 321-323; Stroup 2010: 61). Podobnie o odpoczynku pisał Seneka, który w traktacie De Otio nawiązując do myśli Arystotelesa twierdzi, że mędrzec przedkłada odpoczynek nad karierę polityczną, dzięki czemu może bardziej przysłużyć się potomności, niż przez bezpośrednie zaangażowanie w życie społeczne (Seneka 1989: VI, 676-677).

Myśl wczesnochrześcijańska w znacznym stopniu przejęła od Greków i Rzymian sposób rozumienia odpoczynku, podkreślając wagę aktywności umysłu i życia kontemplatywnego. Św. Augustyn w dziele De vita beata wskazał, że prawdziwie szczęśliwy może być tylko ten, kto zdobył mądrość. Dla Augustyna mądrość oznacza zaś właściwą miarę duszy, jej równowagę. Pełnię mądrości osiągnąć może natomiast tylko ten, kto poświęca się kontemplacji Boga - Miary Najwyższej (Augustyn 20o6: 4.33-4.34).

Arystotelesowska koncepcja odpoczynku domagała się jednak gruntownej rewizji wraz z rozwojem życia monastycznego. Cedowanie pracy fizycznej na niewolników, kobiety i rzemieślników pozwalało starożytnym obywatelom Grecji i Rzymu praktykować odpoczynek rozumiany jako nienastawioną na użyteczność aktywność umysłową. Zmiany społeczne i mentalne, jakie dokonały się dzięki chrześcijaństwu spowodowały jednak, że nie było to dłużej 
możliwe. Klasyczny sposób rozumienia odpoczynku kontrastował bowiem z wysoko cenionym życiem zakonnym. Dobrze ilustruje to motto reguły św. Benedykta - ora et labora. W konsekwencji chrześcijaństwo doprowadziło do harmonijnego połączenia pracy fizycznej i życia kontemplatywnego przy jednoczesnym zachowaniu wyższości tego ostatniego. Miało to istotny wpływ na rozumienie odpoczynku (Sager 2013: 7). Odpoczynek stał się bowiem dobrem bardziej dostępnym szerokim rzeszom średniowiecznej Europy. Zagwarantowanie odpowiedniej liczby dni wolnych od prac fizycznych dawało wytchnienie ciału, zaś celebrowanie uroczystości religijnych sprzyjało rozwojowi duchowemu także osób niewykształconych. W średniowiecznej Europie powszechne obciążenie pracą nie było bowiem tak duże, jak się to dziś często uważa. Liczba wolnych od pracy niedziel wraz z dodatkowymi świętami kościelnymi stanowiła ok. 100 dni w roku. Potwierdza to kalendarz wprowadzony w 1422 r. przez poznańskiego biskupa Andrzeja Łaskarza (Sadowski 2015: 299). Dla porównania w roku 2017 w Polsce obowiązywało 115 dni ustawowo wolnych od pracy, spośród których znaczną część wiele osób przeznacza na pracę (Infor.pl, 2017).

Tematykę odpoczynku podejmowano także w nowożytności. Tomasz Morus jest najprawdopodobniej pierwszym nowożytnym myślicielem, który przedstawia koncepcję odpoczynku/czasu wolnego, będącego nie tylko ekskluzywnym przywilejem elit, lecz powszechnym prawem całego społeczeństwa. Morus opisując w 1516 r. organizację mitycznego państwa - Utopia zauważa, że doba dzieli się tam na 24 równe godziny, z czego mieszkańcy tej idyllicznej krainy przeznaczają na pracę fizyczną jedynie sześć godzin w dwóch trzygodzinnych etapach oddzielonych obiadem i dwugodzinną przerwą. Na sen poświęcają osiem godzin, zaś pozostały czas spędzają na różnych aktywnościach, zależnie od indywidualnych upodobań. Najczęściej w czasie tym poświęcają się nauce, doskonaleniu kunsztu wykonywanego rzemiosła, a po kolacji jedną godzinę każdego dnia poświęcają na zabawy przy muzyce, rozmowy i gry podobne do szachów (Morus 1947: 55-57).

Do XX w. dni wolne były zwykle dniami pojedynczymi, które wykorzystywano głównie na wytchnienie od trudu codziennej pracy, nie sposób więc było wykorzystywać ich na dalsze podróże. Opisany przez Tomasza Morusa ustrój Utopii przewidywał zaś po raz pierwszy podróże wszystkich obywateli zarówno w celu odwiedzin przyjaciół, jak i dla czystej przyjemności. Zgodę na takie wyjazdy można było łatwo uzyskać, a list polecający od księcia zapewniał podróżnym darmowy nocleg i posiłki w miejscach, które odwiedzali. Mieszkańcy miast, jeśli mieli taką ochotę, wybierali się także na krótkie wycieczki po okolicy. Jeśli jednak podróżny w jakimś miejscu przebywał dłużej niż jedną dobę zobowiązany był do pracy na rzecz goszczącej go społeczności w takim samym wymiarze, w jakim poświęcali się jej gospodarze. Chociaż obywatele Utopii dysponowali znaczną ilością czasu wolnego i dużą różnorodnością jego wykorzystywania, to Morus jednoznacznie podkreśla, że w tej idyllicznej krainie nie było miejsca na lenistwo (Morus 1947: 67-68).

O powszechnym dostępie do odpoczynku można mówić jednak dopiero od stosunkowo niedawna. Do początku XX w. czas wolny był bowiem przywilejem nielicznych. Jako pierwsi prawo do płatnego tygodniowego urlopu wywalczyli w roku 1910 holenderscy szlifierze diamentów. Kilkanaście lat później podobne prawa uzyskali robotnicy w Wielkiej Brytanii, a w 1936 r. płatny urlop przysługiwał już wszystkim osobom zatrudnionym we Francji. Polscy pracownicy uzyskali prawo do płatnego wypoczynku stosunkowo wcześnie. Sejm II RP ustawą z 16 maja 1922 r. wprowadził prawo, mocą którego robotnikowi po przepracowaniu 1 roku przysługiwało 8 dni nieprzerwanego płatnego urlopu, zaś po przepracowaniu 3 lat okres ten wydłużał się do 15 dni (Kaczmarzyk 2014: 4). 


\section{Współczesne ujęcie wypoczynku}

Niemiecki filozof Josef Pieper jest zdania, że właściwe ujęcie odpoczynku/czasu wolnego (ang. leisure) wymaga od dzisiejszego człowieka zdrowego dystansu. Współczesny świat, szczególnie zaś cywilizacja zachodnia, charakteryzuje się bowiem, m.in. nieodpartym pragnieniem działania oraz jest nastawiona na osiąganie utylitarnych celów, co utrudnia docenienie wagi odpoczynku. Odpoczynek jest dziś „kolonizowany” przez zorganizowaną rozrywkę i konsumpcję (Pieper 2009: 19; Rojek 2010: 94).

Odpoczynek jest też dziś często postrzegany jako coś całkowicie przypadkowego, obcego i pozbawionego sensu, a niekiedy nawet niestosownego pod względem moralnym. Odpoczynek bywa wręcz traktowany jako usprawiedliwienie lenistwa, bezczynności i próżniactwa. W odróżnieniu od takiego podejścia, tradycja chrześcijańska potępia lenistwo ale jednoznacznie potwierdza potrzebę odpoczynku i zwraca uwagę na związek pomiędzy lenistwem i niezdolnością do odpoczynku. Lenistwo jest bowiem, w tym ujęciu, źródłem niepokoju ducha, który uniemożliwia właściwy odpoczynek, stąd takich terminów, jak „odpoczynek” (ang. leisure) i „bezczynność” (ang. idleness) nie traktowano w myśli chrześcijańskiej synonimicznie. Prawdziwy odpoczynek jest bowiem możliwy tylko wówczas, gdy człowiek jest ze sobą w jedności, gdy jest pogodzony ze swoim życiem i cieszy się pokojem ducha. Odpoczynek nie jest bowiem jedynie konsekwencją czynników zewnętrznych: czasu wolnego, wakacji czy urlopu. Czynniki te są wprawdzie niezbędne, ale niewystarczające do właściwego odpoczywania. Odpoczynkiem można bowiem cieszyć się tylko wówczas, gdy człowiek posiądzie odpowiednie nastawienie mentalne i duchowe. Odpoczynek zakłada więc nie tylko brak aktywności, ale także wewnętrzny spokój i ciszę. Chodzi więc o swoiście rozumianą postawę niebycia zajętym oraz pozwalania na to, by życie toczyło się (Pieper 2009: 45-46). Przejawia się to w prowadzeniu życia kontemplatywnego, zdolności do refleksji i nawiązywania głębokich relacji międzyludzkich (Rojek 2010: 94).

Josef Pieper definiuje odpoczynek (ang. leisure) jako formę ciszy, która jest warunkiem koniecznym respektu dla rzeczywistości. Cisza nie oznacza jednak milczenia (ang. dumbness) lub braku hałasu (ang. noiselessness); należy ją raczej rozumieć jako niezmąconą władzę duszy zdolnej do „odpowiadania” na rzeczywistość świata. Odpoczynek jest więc otwartą i refleksyjną postawą umysłu oraz zdolnością do zanurzenia się w pełni stworzenia (Pieper 2009: 46).

Warunkiem właściwego zrozumienia odpoczynku jest dostrzeżenie, że u jego podstaw leży aprobata prawdziwej natury człowieka i respektowanie znaczenia wszechświata. Ważnym elementem odpoczynku jest afirmacja. Dobrze wyraża to Księga Rodzaju, która wskazuje, że zanim Bóg odpoczął - stwierdził, że wszystko, co stworzył było „bardzo dobre” (Rdz 1,31). Odpoczynek jest więc świętowaniem zakończenia pracy, które potwierdza jej wartość. Świętowanie jest także źródłem odpoczynku i nadaje mu wewnętrzne znaczenie (Pieper 2009: 49).

O odpoczynku nie może być mowy, gdy mamy do czynienia z łańcuchem zdarzeń, którego celem jest jedynie osiągnięcie jakiegoś utylitarnego dobra. Przerwa w pracy, niezależnie od jej długości, w celu poprawienia kondycji fizycznej, psychicznej czy duchowej nie jest więc odpoczynkiem. Celem odpoczynku nie jest bowiem powrót do oczekiwanej kondycji człowieka, aby osiągał właściwą wydajność pracy. Odpoczynek nie ma też jedynie funkcjonalnego charakteru. Celem i usprawiedliwieniem odpoczynku jest umożliwienie człowiekowi bycie w pełni człowiekiem. To zaś nie wyczerpuje się w pracy na rzecz zaspokojenia codziennych potrzeb, ale realizuje się także w zdolności do pojmowania świata jako całości i aktualizacji pełnej potencjalności człowieka. Tak więc zdolność do odpoczynku należy do fundamentalnych władz ludzkiej duszy (Pieper 2009: 50).

Zdaniem Josefa Piepera istotą odpoczynku jest świętowanie, zaś najbardziej uroczystą formą świętowania jest oddawanie czci 
Bogu, w którym człowiek odnawia swoją prawdziwą wartość jako osoba i afirmuje wewnętrzną wartość stworzenia. Rezygnacja $\mathrm{z}$ religijnego wymiaru świętowania i próba zastępowania go rozrywką, zabawą lub sportem jest dla świętowania zabójcze. Czyni bowiem z pracy swoiście rozumiany kult. Pieper zwraca też uwagę, że świętowanie i oddawanie czci religijnej nie jest ucieczką od pracy, lecz jedynie oddzieleniem od niej, dzięki czemu możliwe jest dostrzeżenie właściwego znaczenia pracy. Bez tego zaś, niemożliwy jest prawdziwy odpoczynek (Pieper 2009: 65-75).

Wydaje się zatem, że wizja odpoczynku obowiązująca we współczesnych społeczeństwach industrialnych znaczacco odbiega od nawiązującej do tradycji antycznej wizji Piepera. Odpoczynek utożsamiany jest dziś bowiem najczęściej z aktywnością, działaniem i posiadaniem, nie zaś z medytacją, świętowaniem i kultem. Współczesny przedstawiciel cywilizacji zachodniej najczęściej łączy odpoczynek z kulturą konsumpcyjną, kupowaniem dóbr, pracą w ogródku i ćwiczeniami fizycznymi. Kontemplacja dla niej samej została zastąpiona przez działanie nastawione na uzyskanie bezpośrednich korzyści. Niektórzy uważają nawet, że należy odejść od klasycznego ujęcia odpoczynku i dostosować je do wymogów współczesnego społeczeństwa przemysłowego (Rojek 2010: 94-95).

Próbę taką dostrzegamy we współczesnych ujęciach odpoczynku, które podkreślają doniosłość wytchnienia od obowiązków zawodowych i domowych oraz wagę rozrywki, zabawy, rekreacji, sportu i różnych przejawów kultury konsumpcyjnej. Wiele współczesnych ujęć odpoczynku wciąż uwzględnia jednak bezinteresowne samokształcenie i rozwój osobisty oraz troskę o pogłębianie relacji międzyosobowych (Kolny 2014: 29). Małgorzata Bombol analizując różne definicje czasu wolnego/ odpoczynku wskazuje na trzy zasadnicze podejścia do tego zagadnienia. Mówi więc o: 1) „czystym” czasie wolnym; 2) czasie specyficznych zachowań; oraz 3) duchowym wymiarze czasu wolnego. Charakteryzując poszczególne podejścia do czasu wolnego/ odpoczynku wskazuje na jego specyficzne cechy. „Czysty” czas wolny jest - w jej opinii - naturalnym elementem ludzkiej egzystencji, jest wydzielany z 24-godzinnego budżetu czasu oraz jest wolny od czynności obligatoryjnych. Czas specyficznych zachowań charakteryzuje się tym, że jest pożytkowany na bierne lub czynne działania sprawiające przyjemność. Charakteryzując zaś duchowy wymiar czasu wolnego Małgorzata Bombol podkreśla, że służy on realizacji wyższych potrzeb psychicznych człowieka (Bombol 2008: 19-20).

Pobieżna analiza różnych ujęć odpoczynku/czasu wolnego wskazuje na tendencję stopniowego odchodzenia od klasycznej koncepcji odpoczynku rozumianego głównie jako aktywności intelektualnej i duchowej, która nie jest nastawiona na bezpośrednie korzyści. Koncepcja ta jest dziś zastępowana przez odpoczynek rozumiany jako okazja do rozrywki, zabawy, rekreacji, sportu oraz różnych przejawów kultury konsumpcyjnej, które mają na celu osiąganie przyjemności i doraźnych korzyści.

\section{Współczesne wyzwania wobec odpoczynku}

Konrad Lorenz już w latach 70. XX w. przedstawił wnikliwą analizę wyzwań, przed jakimi staje dziś człowiek (Lorenz 1973). Znaczna część tych wyzwań dotyczy wprost pracy i odpoczynku człowieka (Sadowski 2015: 201-216; Dzwonkowska 2011). Stwierdził on wręcz, że w stylu życia współczesnych mieszkańców Zachodu mają miejsce zmiany, które grożą destrukcją człowieczeństwa. W swych badaniach Lorenz odwołuje się do koncepcji człowieka, którego ujmuje jako byt trójelementowy, złożony z ciała, psychiki (duszy) i ducha wyrażającego się w kulturze. Przyczyną współczesnej destrukcji człowieczeństwa - zdaniem Lorenza - jest to, że „w rozwoju człowieka uczestniczą procesy dwóch rodzajów, które wprawdzie toczą się w bardzo różnych tempach, ale są ściśle powiązane wzajemnym 
oddziaływaniem: powolny proces ewolucyjny i wielokrotnie szybszy rozwój kulturowy" (Lorenz 1977: 296). Wraz z rozwojem cywilizacji różnica tempa przebiegania obu tych procesów stale się powiększała. Jednak począwszy od nowożytności zjawisko to jeszcze bardziej przybrało na sile sprawiając, że człowiek doświadcza swego rodzaju wewnętrznego rozdarcia. Jego depozyt biologiczny (ciało i dusza) nie nadąża bowiem za jego depozytem kulturowym (duchem). Prowadzi to do destrukcji człowieczeństwa człowieka, tzn. redukcji człowieka poprzez eliminację specyficznych mu własności. Lorenz wskazuje osiem zjawisk, które ilustrują ten proces i nazywa je „grzechami śmiertelnymi" cywilizowanej ludzkości (Lorenz 1973). Przynajmniej połowa tych "grzechów” wprost łączy się z pracą i odpoczywaniem.

Zdaniem Lorenza jednym z głównych zagrożeń, przed jakimi staje dziś człowiek jest przeludnienie. Nie chodzi mu jednak o zagrożenia środowiskowe i społeczno-ekonomiczne spowodowane rosnącą populacją człowieka. Zwraca natomiast uwagę, że dzisiejszy człowiek zmuszony jest do życia w wielkich skupiskach ludzkich, co paradoksalnie wcale nie wpływa na pogłębianie jego relacji międzyosobowych. Wręcz przeciwnie, z jednej strony staje się to przyczyną agresji wobec otaczających go ludzi, z drugiej zaś „znieczulicy” wobec nich. W konsekwencji mamy do czynienia z samotnością i apatią człowieka zagubionego w bezimiennym tłumie (Lorenz 1973: 11-14, 22). Wydaje się, że tego typu nastawienia stanowią poważną przeszkodę w osiągnięciu spokoju ducha, który jest niezbędny do właściwego odpoczywania.

Drugim niebezpiecznym zjawiskiem grożącym człowiekowi jest degradacja przyrody. Zdaniem Lorenza najbardziej niebezpieczne dla człowieczeństwa człowieka nie są jednak skutki kryzysu ekologicznego, lecz brak kontaktu z przyrodą, okazji do doświadczenia jej piękna i harmonii oraz odczucia szacunku względem niej. Brak bezpośredniego kontaktu z przyrodą prowadzi do zaniku wrażliwości estetycznej człowieka, ta zaś - jego zdaniem - łączy się z wrażliwością etyczną (Lorenz 1973: 15-23; Łepko 2006: 8o). Wszystko to rzutuje na stan niektórych specyficznie ludzkich przymiotów, które odgrywają ważną rolę w poczuciu harmonii z całą rzeczywistością i umożliwiają właściwy odpoczynek.

Trzecie zjawisko zagrażające człowieczeństwu człowieka Lorenz nazwał wyścigiem człowieka z samym sobą. Określił w ten sposób niekończącą się neurotyczną pogoń człowieka za sukcesem oraz związane z tym niekontrolowane współzawodnictwo. Jego zdaniem współczesna hiperaktywność tak bardzo angażuje człowieka, że nie jest już on zdolny do refleksji nad celem swych aktywności oraz ich skutkami. To zaś „może doprowadzić do tego, że środek do celu przeradza się w cel sam w sobie, a skutek tego jest taki, że człowiek staje się niewolnikiem aparatu produkcyjnego. Tym samym zamyka się diabelski krąg wzrostu gospodarczego wciągającego ludzkość w swe miażdżące tryby" (Lorenz 1986: 157). Niekontrolowana pogoń za bogactwem oraz wycieńczenie współzawodnictwem prowadzą do głębokiego lęku przed konkurentami, podjęciem niewłaściwych decyzji i popadnięciem w biedę. Konsekwencją tej hiperaktywności oraz lęku jest niezdolność do samotnego spędzania czasu. Człowiek obawia się ciszy, która prowokuje do refleksji, ta zaś mogłaby mu ukazać jego dramatyczną sytuację. Lorenz jest zdania, że to właśnie jest przyczyną wszechobecnego hałasu, którym otacza się dziś człowiek. Nieustannie włączone radioodbiorniki i telewizory towarzysząc człowiekowi na każdym kroku, uniemożliwiają mu refleksję nad swym życiem i zmianę jego stylu (Lorenz 1973: 28-29). W konsekwencji, pogrążony w niekontrolowanej aktywności i uciekający od refleksji nad swym życiem człowiek boi się odpoczynku, który mógłby ukazać mu jego dramatyczną sytuację.

Wśród niepokojących zjawisk towarzyszących dziś człowiekowi Lorenz wymienia także „entropię uczuć”. Uważa, że jest ona konsekwencją powszechnego nadużywania 
leków znieczulających, które przyjmuje się nawet w przypadku niewielkiego dyskomfortu fizycznego lub psychicznego. Człowiek stał się przez to uzależniony od farmakologicznego dobrostanu. Prowadzi to człowieka z jednej strony do utraty odporności na ból, z drugiej zaś do zobojętnienia na przyjemności. Farmakologiczne „znieczulenie” skutkuje też brakiem gotowości do ponoszenia wysokich ofiar i podejmowania wielkich trudów w celu osiągania celów prowadzących do wielkiego zysku/przyjemności w odległej perspektywie czasowej. Wszystko to sprawia, że współczesny człowiek „niewieścieje” i staje się coraz bardziej znudzony, obojętny i zblazowany, niezdolny do stawiania czoła wyzwaniom życia (Łepko 2001: 159-16o; Piątek 1998: 159-16o). Skutki tego zjawiska najbardziej rzutują na relacje międzyludzkie. Największe bowiem poczucie szczęścia i cierpienia wiąże się z relacjami między małżonkami, rodzicami i dziećmi oraz przyjaciółmi. Z lęku przed możliwością doznania traumatycznych doświadczeń człowiek unika więc bliskości drugiego człowieka (Lorenz 1973: 39).

Lorenz wskazuje też, że człowiek dążąc do zaspakajania głodu przyjemności, zmuszony jest do poszukiwania wciąż nowych bodźców, z czasem uodparnia się bowiem na dotychczasowe. Nazywa to zjawisko „neofilią”. Dla człowieka systematycznie ulegającego „śmiertelnym grzechom” cywilizowanej ludzkości z czasem wszystko obojętnieje i może być zastąpione. Dotyczy to rzeczy, ulubionych zwierząt, a nawet osób. Zjawisko „neofilii” tłumaczy także pragnienie zaspokojenia głodu głębokich relacji poprzez nieustanne nabywanie dóbr materialnych (Lorenz 1973: 40-41).

Wydaje się, że analiza procesów cywilizacyjnych, jaką niemal 50 lat temu przeprowadził Konrad Lorenz nie straciła nic na aktualności. Pragnienie sukcesu i stale rosnące tempo życia utrudnia człowiekowi odpoczynek, a niekiedy nawet mu go uniemożliwia. Przepracowani karierowicze dążący do osiągnięcia kolejnego awansu zawodowego i zdobycia fortuny są niezdolni do odpoczynku, w tradycyjnym znaczeniu tego terminu. Konsekwencją współczesnej mentalności sukcesu mierzonego jedynie gratyfikacją ekonomiczną i zajmowanym szczeblem kariery są zjawiska, które zamiast rozwijać człowieka, prowadzą do jego degradacji. Widać to szczególnie wyraźnie na przykładzie ofiar „wyścigu szczurów", który wywołując długotrwałe stresy może doprowadzić do depresji, kryzysu relacji międzyludzkich, wypalenia zawodowego, pracoholizmu, cukrzycy, alergii i nałogów. Zauważa się też, że u osób w sposób drastyczny i długotrwały przeciążonych obowiązkami zawodowymi pojawia się problem tzw. „odrytmizowania”. Obowiązki zawodowe zaczynające się wczesnym rankiem i trwające do późna w nocy, niekiedy pełnione przez długi okres czasu w rytmie pracy siedmiu dni w tygodniu, sprzyjają zakłóceniu rytmu posiłków i snu, pór dnia i nocy, a nawet pór roku (Pluta 2013: 130). Taki styl życia uniemożliwia właściwy odpoczynek i prowadzi do zgubnych dla człowieka konsekwencji. Zapędzenie, jakiemu ulega człowiek prowadzi do zatraty celu pracy, która sama staje się celem aktywności człowieka. To zaś powoduje, że ekonomia dominuje wszystkie inne sfery życia człowieka, prowadząc do zagłuszania wyższych jego potrzeb. W niektórych przypadkach nawet sam udział w tej szaleńczej gonitwie staje się podstawą samooceny człowieka. Ujawnia się to szczególnie wyraźnie w niechęci, a nawet lęku przed odchodzeniem na emeryturę (Sadowski 2016: 34).

Innym poważnym wyzwaniem wobec odpoczynku jest współczesna kultura rozrywki. Zauważa się bowiem tendencje do redukowania odpoczynku jedynie do rozrywki i robienia zakupów. Taki model odpoczynku z pewnością nie zaspakaja wszystkich potrzeb człowieka, nie umożliwia mu też właściwego, głębokiego odpoczynku, a co za tym idzie - nie pomaga w osiągnięciu pokoju ducha i jedności z sobą samym, innymi osobami i światem. Ograniczenie odpoczynku jedynie do rozrywki powoduje, że nadmiar tak rozumianego odpoczynku skutkuje znudzeniem, zmęczeniem i niepokojem. Z drugiej zaś strony ograniczenie odpoczynku 
jedynie do snu dawkowanego w nadmiarze także męczy, czyni człowieka ospałym i apatycznym. Odpoczynek, który nie uwzględnia wyższych potrzeb człowieka nie dostarcza mu satysfakcji, która wypełnia jego intelekt i ducha (Pieper 2009: 69).

\section{Ku prawdziwie zrównoważonej turystyce}

Debata nad zrównoważoną turystyką trwa od kilku dekad. Różne organy ONZ, UE oraz innych organizacji międzynarodowych i rządów państw wydały liczne dokumenty na ten temat. Jedną z najczęściej przywoływanych definicji zrównoważonej turystyki jest definicja opublikowana w dokumencie wydanym wspólnie przez United Nations Environment Programme oraz World Tourism Organization (UNEP, WTO, 2005: 11). Dokument ten stwierdza, że zrównoważona turystyka uwzględnia swój wpływ na trzy zasadnicze aspekty zrównoważonego rozwoju: aspekt środowiskowy, aspekt ekonomiczny oraz aspekt społeczno-kulturalny. Tylko zachowanie równowagi pomiędzy wszystkimi tymi aspektami gwarantuje zrównoważony rozwój w dalekosiężnej perspektywie czasowej. Dokument ten stwierdza ponadto, że dla osiągnięcia tego celu turystyka powinna:

1. w sposób optymalny korzystać z zasobów przyrodniczych, które stanowią kluczowy element rozwoju turystyki, chroniąc jednocześnie podstawowe procesy ekologiczne, zasoby środowiskowe i bioróżnorodność;

2. respektować społeczno-kulturową oryginalność społeczności przyjmującej turystów, chronić ich dziedzictwo kulturowe i tradycyjne wartości, a także przyczyniać się do tolerancji i międzykulturowego porozumienia;

3. zapewnić realne, długoterminowe inwestycje gospodarcze, które dostarczą społeczno-ekonomicznych korzyści wszystkim stronom, włączając w to stabilny poziom zatrudnienia, możliwość zarobkowania, usługi społeczne na rzecz ludności miejscowej oraz zmniejszanie poziomu jej ubóstwa.
Zrównoważona turystyka ma zatem na celu takie kształtowanie polityki organizatorów turystyki oraz zachowań turystów, które przyczynią się do poszanowania przyrody i rozwoju ekonomicznego społeczności lokalnej oraz wpłyną korzystnie, pod względem etycznym i społecznym, na lokalne społeczności (Gołembski 2006: 371).

Wiele wskazuje na to, że zdefiniowana w ten sposób zrównoważona turystyka nie jest $w$ stanie w pełni zrealizować stawianych sobie celów bez odpowiedniej koncepcji odpoczynku. Tak określony model turystyki zdaje się bowiem nie uwzględniać wszystkich potrzeb człowieka, czyli nie w pełni realizuje to, co zwykle określa się społecznym filarem zrównoważonego rozwoju. Warunkiem respektu dla społeczno-kulturowej oryginalności społeczności przyjmujących turystów, ochrony jej dziedzictwa kulturowego i systemu wartości oraz tolerancji i porozumienia kulturowego jest tylko taki turysta, który dzięki temu, że sam zaspakaja wszystkie (także te wyższe) ludzkie potrzeby jest zdolny do respektu i docenienia przejawów kultur odwiedzanych społeczności, które nie ograniczają się jedynie do rekreacji, zabawy i rozrywki. Używając terminologii Konrada Lorenza można powiedzieć, że oferta turystyczna, która ma spełniać warunki turystyki zrównoważonej, powinna dotyczyć wszystkich „warstw” człowieka, tzn. jego ciała, duszy (emocji) i ducha - wyrażającego się w kulturze.

Poważnym wyzwaniem jest zatem przygotowanie takiej oferty turystycznej, która będzie uwzględniała zbyt często pomijanego ludzkiego „ducha”. Chodzi tu bowiem o zaplanowanie aktywności, które pozwolą turyście być aktywnym uczestnikiem odwiedzanej kultury. Poznanie systemu organizacji społeczności lokalnej, w tym modelu więzi rodzinnych, a ponadto sztuki, historii, zwyczajów, systemu wartości i religii wyznawanych przez odwiedzane społeczności pozwoli turyście odejść od stereotypowych opinii na temat goszczącej go społeczności. Będzie też okazją do skonfrontowania tych sfer ludzkiego życia z właściwą jemu kulturą. 
Ponadto oferta prawdziwie zrównoważonej turystyki powinna uwzględniać potrzebę doświadczenia przyrody, zachwycenia się nią, dostrzeżenia jej wartości, a być może nawet wzbudzenia odniesień religijnych. W pełni zrównoważona turystyka winna też stwarzać warunki do pogłębienia więzi pomiędzy bliskimi sobie osobami, które wspólnie odpoczywają.

Tak rozumiana turystyka wymaga jednak nie tylko przygotowania odpowiedniej oferty odpoczynku przez organizatorów, niezbędne jest także odpowiednie przygotowanie samego turysty. Już Arystoteles bowiem zwracał uwagę na to, że odpoczynek jest tak wielkim wyzwaniem, iż niezbędne jest gruntownego do niego przygotowanie. Zdaniem Arystotelesa przygotowanie to winno obejmować zarówno potrzebną wiedzę, jak i właściwe wychowanie (Arystoteles 2003: VIII,2.5). Nie chodzi tu jednak w pierwszym rzędzie o szeroką wiedzę na temat własnej kultury oraz kultur odwiedzanych, ważniejsza wydaje się być tu wiedza na temat samego odpoczywania, sposobu przygotowania się do niego oraz zrozumienia mechanizmów rządzących stylem życia współczesnego człowieka. W przeciwnym bowiem razie gwałtownie wyrwany z kieratu swych zajęć turysta nie będzie zdolny do właściwego odpoczynku, uniemożliwi mu to "syndrom odstawienia” hiperaktywności. Charakteryzujący się niebywałym tempem życia współczesny człowiek musi więc nauczyć się przygotowywać do odpoczywania. Niezbędna jest do tego odpowiednia wiedza, równie ważne jest jednak wychowanie. Zrównoważony model stylu życia w rodzinie, która potrafi zachować właściwą równowagę między rytmem pracy i nauki oraz rytmem odpoczynku i wspólnego spędzania czasu dzieci i rodziców stwarza dobrą podstawę do kształtowania właściwych wzorców odpoczywania.

Wydaje się też, że pomocna w przygotowywaniu do prawdziwie zrównoważonej turystyki może się okazać promocja właściwej koncepcji postępu. Współczesne badania wskazują bowiem, że nowożytna redukcja postępu do jego wymiaru horyzontalnego może prowadzić do obsesyjnego konsumpcjonizmu i uniemożliwić zaspokojenie wyższych aspiracji i potrzeb człowieka (Jonas 1995: 224; Łepko 2010: 128-129). Postęp powinien zatem uwzględniać także wertykalny wymiar ludzkiej egzystencji, która wyraża się m.in. w kulturze wysokiej, doskonaleniu moralnym i odniesieniach do rzeczywistości sacrum. Promocja takiego modelu postępu z pewnością sprzyja zrównoważonemu stylowi życia, który z kolei wychodzi naprzeciw prawdziwie zrównoważonej turystyce. Programy wychowawcze i edukacyjne, które będą uczyły, że o wartości człowieka nie stanowi jedynie to, ile posiada ale to, jakim jest człowiekiem, wydają się niezbędne dla ustrzeżenia go przed „wyścigiem szczurów”, obsesyjną gonitwą za dobrami materialnymi i ograniczeniem wypoczynku do rozrywki, rekreacji i bezczynności. Wszystko to stanowi wielkie wyzwanie dla współczesnych rodzin, systemów edukacyjnych oraz mediów, które poprzez kampanie społeczne mogą znacząco przyczyniać się do pozytywnych zmian w tym względzie.

\section{Zakończenie}

Wydaje się, że refleksja nad odpoczynkiem stanowi ważny element zrównoważonej turystyki. Tylko uwzględnienie wszystkich potrzeb człowieka daje bowiem nadzieję na realizację społeczno-kulturowego aspektu tego modelu turystyki. Warunkiem osiągnięcia tego celu jest jednak stworzenie takiej koncepcji odpoczynku, która połączy w sobie zarówno klasyczne, jak i współczesne rozumienie odpoczynku. Ponieważ oprócz współczesnego utożsamiania odpoczynku z relaksem, rozrywką, zabawą i rekreacją powinien on uwzględniać także kulturowe i duchowe aspiracje człowieka. Podstawą właściwie rozumianego odpoczynku jest bowiem akceptacja natury człowieka, afirmacja otaczającej go rzeczywistości oraz dążenie do aktualizacji całej jego potencjalności (Pieper 2009: 49-50).

Nawiązując do zjawisk, jakie utrudniają właściwy odpoczynek człowieka należy stwierdzić, że odpoczynek powinien 
uwzględniać potrzebę kontaktu człowieka z przyrodą i kulturą, odpowiedni dystans do pełnionych obowiązków zawodowych, przestrzeń do nawiązywania i pogłębiania więzi międzyosobowych oraz rozwój intelektualny i duchowy. Odpoczynek powinien być także okazją do wyciszenia, odnalezienia pokoju ducha oraz harmonii ze sobą, ludźmi i całą rzeczywistością. Ważnym komponentem odpoczynku jest także umiejętność niebycia zajętym oraz zgoda na to, by życie toczyło się swoim torem (Pieper 2009: 45-46). Chodzi tu o zdolność do wyciszenia i pogłębionej refleksji nad prowadzonymi aktywnościami, ich celami, a ostatecznie nad sensem życia.

Wydaje się zatem, że bez uwzględnienia tak rozumianego odpoczynku nie będzie możliwe osiągnięcie niektórych celów, jakie ONZ wiąże z promocją turystyki zrównoważonej. Człowiek, który nie zaspokoi swoich potrzeb kulturowych i duchowych, nie osiągnie pokoju ducha i nie będzie w stanie skutecznie chronić różnorodności dziedzictwa kulturowego, ani budować wzajemnego zrozumienia, pokoju i bezpieczeństwa. Pomocą $\mathrm{w}$ rozwiązaniu tego problemu jest myśl wyrażona już przez Arystotelesa - odpoczynek stanowi tak wielkie wyzwanie dla człowieka, że wymaga właściwego wychowania i nabycia niezbędnej wiedzy (Arystoteles 2003: VIII,2.5). Wydaje się, że powinny to uwzględniać współczesne systemy wychowania i kształcenia młodego pokolenia. Troska o wychowanie człowieka do właściwego stylu odpoczynku oraz zapewnienie mu potrzebnej do tego wiedzy wydają się być bowiem niezbędne dla skutecznego wprowadzania zrównoważonej turystyki. Zauważa się więc pilną potrzebę uwzględnienia tej tematyki w programach nauczania oraz wychowania. Tylko właściwe programy wychowawczo-edukacyjne oraz odpowiednia aktywność środków masowego przekazu dają nadzieję na upowszechnienie modelu rozwoju, który uwzględnia zarówno horyzontalny, jak i wertykalny wymiar ludzkiego życia. To zaś pozwoli na zmianę stylu odpoczywania i przyczyni się do popularyzacji turystyki zrównoważonej.

\section{Bibliografia}

Arystoteles, 1996, Etyka nikomachejska, w: Arystoteles, „Dzieła wszystkie”, t. 5, PWN, Warszawa, 7-3oo. Arystoteles, 2003, Polityka, w: Arystoteles, „Dzieła wszystkie", t. 1, PWN, Warszawa.

Augustyn, 2006, O życiu szczęśliwym, Wydawnictwo WAM, Kraków

Bombol M., 2008, Czas wolny jako kategoria diagnostyczna procesów rozwoju społeczno-gospodarczego, Wydawnictwo SGH, Warszawa.

Chick G. E., 1984, Leisure and the Development of Culture, Annals of Tourism Research, vol. 11, 623-628.

Cicero, 2017, Pro P. Sestio Oratio, www.thelatinlibrary.com/cicero/sestio.shtml dostęp: 10.11.2017. Cyceron, 1879, O powinnościach (De officiis), w: Cyceron, Pisma filozoficzne, część 2, tłum. E. Rykaczewski, Nakład Biblioteki Kórnickiej, Poznań, s. 221-394. Tekst dostępny on-line na witrynie Wielkopolskiej Biblioteki Cyfrowej: www.wbc. poznan.pl.

Dzwonkowska D., 2011, Zasada zrównoważonego rozwoju w turystyce, Studia Ecologiae et Bioethicae, vol. 9, no. 2, 23-41.

Gołembski G. (red.), 2006, Kompendium wiedzy o turystyce, PWN, Warszawa.

Infor.pl, 2017, Dni wolne od pracy 2017, www.kadry.infor.pl/kadry/indywidualne_prawo_pracy/ czas_pracy/743871,Dni-wolne-od-pracy-2017.html, dostęp: 12.07.2017.

Jonas H., 1995, Zasada odpowiedzialności, tłum. M. Klimowicz, Wydawnictwo Platan, Kraków.

Jurewicz O., 2001, Stownik grecko-polski, t. 2, PWN, Warszawa.

Karczmarzyk Ł., 2014, 92 lata temu Polacy uzyskali prawo do urlopu, Wiadomości Związkowe z 16 lipca 2014, no. 13(322), 4.

Kolny B., 2014, Czas wolny wświetle zrównoważonego rozwoju, Konsumpcja i Rozwój, vol. 2, no. 7, 28-38.

Lorenz K., 1973, Civilized Man's Eight Deadly Sins, Harcourt Brace Jovanovich, New York.

Lorenz K., 1977, Odwrotna strona zwierciadta, PIW, Warszawa.

Lorenz K., 1986, Regres człowieczeństwa, PIW, Warszawa.

Łepko Z., 2001, Etologiczne inspiracje ekofilozofii, w: Dołęga J., Czartoszewski J., Skowroński A. (red.), „Ochrona środowiska społeczno-przyrodniczego 
w filozofii i teologii", Wydawnictwo UKSW, Warszawa, 135-164.

Łepko Z., 2006, Etologiczna teoria destrukcji cztowieczeństwa, w: Tomczyk J., Abdank-Kozubski A. (red.), „Człowiek w czasie i przestrzeni. Księga pamiątkowa z okazji 70 rocznicy urodzin księdza profesora Bernarda Hałaczka", Wydawnictwo UKSW, Warszawa, 73-85.

Łepko Z., 2010, Ekologiczna wymowa dialektyki oświecenia, Studia Ecologiae et Bioethicae, vol. 8, no. 2, 121-135.

Morus T., 1947, Utopia, tłum. z j. łac. K. Abgarowicz, Instytut Wydawniczy „Kultura”, Poznań.

Panasiuk A., 2006, Ekonomia turystyki, PWN, Warszawa.

Piątek Z., 1998, Osiem grzechów gtównych naszej cywilizacji w ujęciu Konrada Lorenza a kryzys środowiskowy, w: Dębski J. (red.), „Humanistyka, przyrodoznawstwo, technika w obliczu kryzysu biosfery", Wyższa Szkoła Pedagogiczna, Olsztyn, 153-163.

Pieper J., 2009, Leisure: The Basis of Culture, Ignatius Press, San Francisco.

Pluta A., 2013, Myślenie strategiczne o pracownikumożliwość czy potrzeba wspótczesnej organizacji?, Management and Business Administration. Central Europe, vol. 21, no. 1(120), 124 -136.

Rojek Ch., 2010, Leisure and Emotional Intelligence, World Leisure Journal, vol. 52, no. 4, 274-278.

Sadowski R. F., 2015, Filozoficzny spór o rolę chrześcijaństwa w kwestii ekologicznej, TNFS, Warszawa.

Sadowski R. F., 2016, Rozwój cywilizacyjny wyzwaniem dla kondycji człowieka, w: Gabryszczak R., Jakubowska A. (red.), „Społeczne, ekonomiczne i medyczne aspekty ochrony zdrowia i profilaktyki zdrowotnej", Wydawnictwo Uczelniane Politechniki Koszalińskiej, Koszalin, 17-43.

Sager A., 2013, Philosophy of Leisure, in: Blackshaw T. (ed.), ,Routledge Handbook of Leisure Studies”, Routledge, London, 5-14.

Sahlins M. D., Graeber D., 2017, Stone Age Economics, Routledge, New York.

Seneka, 1989, O bezczynności (De otium), w: Seneka, Dialogi, Instytut Wydawniczy PAX, Warszawa, 666-680.

Smith V. L. (red.), 1989, Hosts and Guests: The Anthropology of Tourism, University of Pennsylvania Press, Philadelphia.

Sondel J., 1979, Stownik tacińsko-polski dla prawników i historyków, Universitas, Kraków.

Stroup S. C., 2010, Catullus, Cicero, and a society of patrons: the generation of the text, Cambridge University Press, Cambridge - New York.

Sutton M. Q., Anderson E. N., 2004, Introduction to Cultural Ecology, AltaMira Press, Walnut Creek.

$\mathrm{UN}, 2015$, Resolution adopted by the General Assembly on 22 December 2015, http://www.un.org/en/ga/ search/view_doc.asp?symbol=A/RES/70/193\&referer=/english/\&Lang=E, dostęp 2.11.2017.

UNEP, WTO, 2005, Making Tourism More Sustainable. A Guide for Policy Makers, UNEP WTO, Paris-Madrid, http://www.unep.fr/shared/publications/pdf/DTIx0592xPA-TourismPolicyEN.pdf dostęp: 9.10.2017.

UNWTO, 2016, 2017 is the International Year of Sustainable Tourism for Development, http://media. unwto.org/press-release/2017-01-03/2017-international-year-sustainable-tourism-development $>$, dostęp: 2.11.2017.

\section{The Influence of the Concept of Leisure on Sustainable Tourism}

\section{Abstract}

The article presents: 1) the evolution of the concept of leisure; 2) the challenges facing contemporary civilization in terms of leisure; and 3) the concept of leisure, which promotes sustainable tourism. According to the author only concept of leisure, which takes into account all the potentiality of human being - with his biological, emotional, spiritual and cultural needs - guarantees effective practice of sustainable tourism. Upbringing and education play an important role in reaching such a concept of leisure.

\section{Keywords}

leisure, free time, sustainable tourism, sustainable development 